\title{
PERSPECTIVES FOR THE DEVELOPMENT OF THE TERRITORY IN THE CONTEXT OF TERRITORY PLANNING DOCUMENTS: A CASE STUDY OF MOLÉTAI DISTRICT MUNICIPALITY
}

\begin{abstract}
Jolanta VALČIUKIENĖ, Department of Land Use Planning and Geomatics, Faculty of Engineering, Vytautas Magnus University, K. Donelaičio g. 58, LT-44248 Kaunas, Lithuania, jolanta.valciukiene@vdu.lt (corresponding author)

Daiva JUKNELIENĖ, Department of Land Use Planning and Geomatics, Faculty of Engineering, Vytautas Magnus University, K.Donelaičio g. 58, LT-44248 Kaunas, Lithuania, daiva.jukneliene@ vdu.lt

Virginija ATKOCEVIČIENÉ, Department of Land Use Planning and Geomatics, Faculty of Engineering, Vytautas Magnus University, K. Donelaičio g. 58, LT-44248 Kaunas, Lithuania, virginija.atkoceviciene@ @du.lt

Edita JUOČYTÉ, Department of Land Use Planning and Geomatics, Faculty of Engineering, Vytautas Magnus University, K. Donelaičio g. 58, LT-44248 Kaunas, Lithuania, editajuocyte@gmail.com
\end{abstract}

Territory planning is a rather complex process involving the combination of the necessary economic, social, cultural and ecological policy expressions related to land use policy. This process is quite complex and lengthy due to the large number of interests involved, which inevitably leads to conflicts, inconsistencies in the solutions of territory planning documents at various levels or inconsistencies in the current territory planning situation with the solutions of territory planning documents. The aim of this article is to analyze the development perspectives of Molètai district municipality territory in the context of territory planning documents. Molètai district municipality was chosen as one of the research objects as one of the 15 Lithuanian municipalities with exceptional landscape and recreational characteristics. After the comparative analysis of the functional zoning solutions of the general plan (hereinafter - GP) and general plan correction territories of 11 Molètai district elderships, it was established that no significant changes have been identified in the regulation of the use of the territory. Meanwhile, after analyzing the compliance of the actual land use of the Moletai district territory with the solutions of the GP correction, land use and protection regulations drawing, it was found that recreational areas around Lake Pagulbis in Alanta eldership are planned, however, according to the current situation the area is dominated by swamps and isolated tree massifs. In the territories of Giedraičiai and Joniškis elderships, according to the solutions provided in the GP correction, the territories are intended for intensive agricultural activities, but they are dominated by forests. The analysis of the development perspectives of the territories of individual elderships revealed that it is expedient to develop intensive agriculture in Joniškis, Balninkai and Alanta elderships. Extensive agriculture - in Balninkai, Alanta and Giedraičiai elderships. Mindūnai, Čiulènai and Videniškès elderships are promising for the development of forest territories. It is most expedient to develop recreation in Mindūnai, Čiulènai and Dubingiai elderships. Comparing the obtained results with the GP correction solutions and the actual use of the territories in the area, it was established that at least one of the functional areas of the territories regulated in the GP correction coincides with the actual use of the territories and the territory development perspective. The biggest discrepancy between the regulated, existing and perspective use of the territories was found in Videniškiai, Dubingiai and Giedraičiai elderships. Meanwhile, in Mindūnai, Joniškis and Balninkai elderships, the actual use of territories is regulated in the correction of the GP, most in line with the planned perspectives of territory development.

Keywords: territory planning, general plan, territory planning documents, territory development, muticriteria analysis

\section{INTROTUCTION}

The European Charter for Regional Planning defines "territory planning" as the process by which the geographical, economic, social, cultural and environmental expressions of public policy must be reconciled with land use policy (European conference ..., 1983). The Law on Territorial Planning of the Republic of Lithuania (hereinafter - RL) stipulates that territory planning is a process that includes the establishment of land use priorities, environmental protection, public health safety, heritage protection and other measures for sustainable territory development (Republic of Lithuania ..., 2021). As a result, territory planning becomes a rather complex and time-consuming process due to the multiplicity of interests involved, and inevitably, various problems emerge in it (Yansui, Yang, 2021). Therefore, one of the factors hindering territory planning is the resolution of conflict situations (Koglin, Pettersson, 2017). There is also a problem the non-compliance of the solutions of the lower level territory planning documents with the solutions of the higher level territory planning documents and the non-compliance of the current situation of the use of territories with the solutions of the territory planning.

Copyright (C) 2021 The Authors. Published by Vytautas Magnus University. This is an open-access article distributed under the terms of the Creative Commons Attribution License (CC BY 4.0), which permits unrestricted use, distribution, and reproduction in any medium, provided the original author and source are credited. 
According to G. Tiškus (2010), the purpose of territory planning documents is to create preconditions for longterm, harmonious and sustainable development of the territory and its economy. The principles of spatial and functional planning are applied in the development planning of foreign municipalities. Spatial planning for municipal development is widely used in the UK, where the new spatial strategic planning framework aims to deliver positive social, economic and environmental outcomes and require active collaboration with stakeholders and institutions that help shape local spaces and provide local services (Local ..., 2007). Meanwhile, in 2007, the scope of the Lisbon Treaty was further extended to include a new - territorial - dimension, i.e. territorial cohesion. The aim of territorial cohesion is to ensure harmonious and balanced development not only within the territory but also throughout the territory of the European Union (Treaty of Lisbon ..., 2007). However, according to L. Dringelis, chaotic use of territories, unregulated stretch of urban territories, urbanization of valuable natural territories, lack of perspectives of territory management and development are clearly visible in Lithuania (Dringelis, 2017).

Changes in the natural conditions of the territory determine the suitability of the land for economic activities. Growing demand for food, feed, fiber, and bioenergy increases land use and seeks trade-offs between different land uses and the preservation of ecosystems (Zabel et al., 2014). The use of agricultural land, forest, and other land plays a key role in promoting sustainable agricultural development (Smith et al., 2014).

The aim of this article is to analyze the development perspectives of Moletai district municipality territory in the context of territory planning documents. The following tasks have been set to achieve the goal:

1. To perform the analysis of the compliance of the Moletai district general plan (hereinafter - GP) and GP correction solutions regulating the use of territories with the actual use of territories.

2. To determine the perspective possibilities of using the territory of Moletai district.

3. To compare the compliance of the possibilities of using the perspective territories of Moletai district with the correction solutions of the Molètai district GP.

\section{MATERIALS AND METHODS}

\section{Research object}

As already mentioned, the Molètai district municipality chosen as the object of research, is situated in the eastern part of Lithuania. The district belongs to Utena County. The region is picturesque and fun in its surroundings. Between the larger hills and the small hills there are about 231 lakes. The relief is characterized by an abundance of hills, clones, ravines, a slope to the west, where most of the country's rivers and streams flow. The new GP 2030 of the Republic of Lithuania, which is being prepared, identifies 15 municipalities with their own forest cover and exceptional recreational features, one of which is Moletai District Municipality (Lithuanian General Plan ..., 2020). The total area of the district is $1368 \mathrm{~km}^{2}$. The territory is divided into 11 elderships (Figure 1).
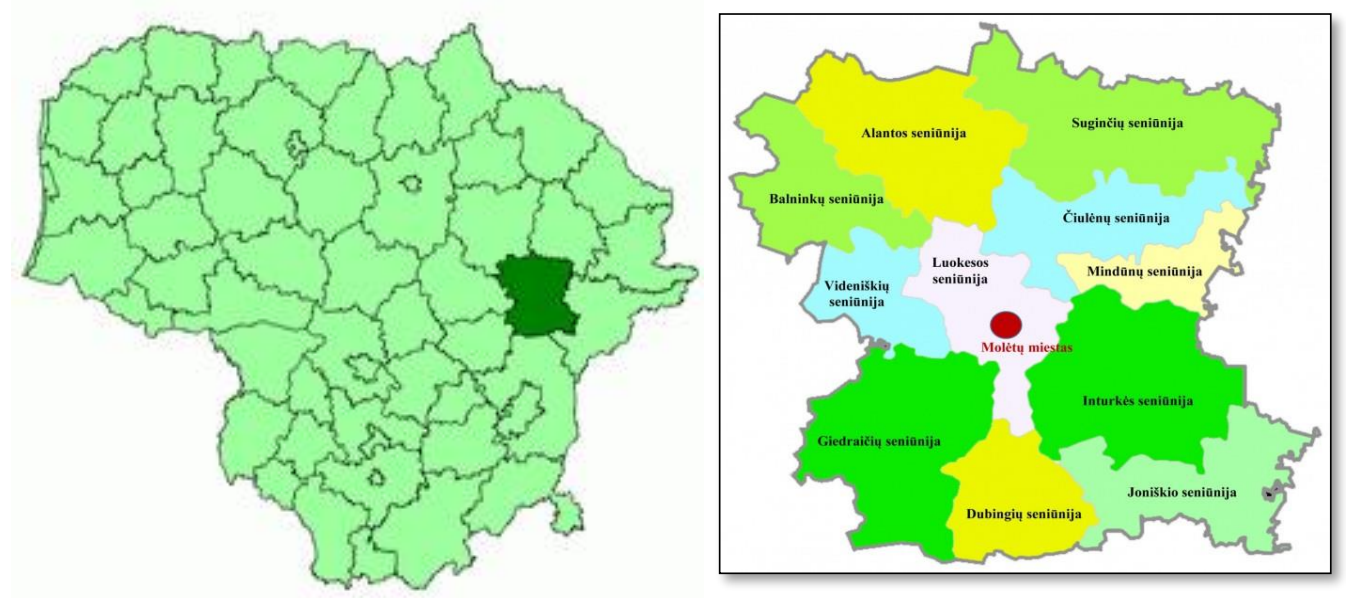

Figure 1. Displacement and territorial division of Molètai District Municipality by elderships (Molètų ..., 2021).

According to the data of January 1, 2020, the largest share of land uses in the district was occupied by agricultural land - 44 percent of the total area of the district. The smallest - roads (2\%), and the remaining land uses were distributed as follows: forests - 31\%, built-up area - 3\%, waters - $9 \%$, other land - $11 \%$ of the total area of the district. The predominant economic activity in the district is agriculture and forestry.

\section{Research data and methods}

Moletai district GP and Molètai district GP correction solutions were analyzed during the research, using the method of comparative analysis. The actual use of the territory for each of the 11 district elderships was also analyzed.

Based on the above-mentioned territory planning documents and applying the method of multicriteria analysis, using the software PROMETHEE, perspective directions of territory development have been determined in all elderships of Molètai district. I.e. taking into account, that according to the GP correction, the priority activities in Molètai district are intensive agriculture, extensive agriculture and forestry, it was determined which district elderships are the most suitable for intensive and extensive agricultural activities according to the set criteria, and where it is expedient to provide 
for forest areas. Also, after assessing the natural and cultural resources of the district, it was determined in which elderships of the district recreational development is expedient. The criteria chosen for the multicriteria analysis and their significance are presented in Table 1.

Table 1. Criteria and justification of their significance for multicriteria analysis.

\begin{tabular}{|c|c|c|c|}
\hline No. & Criterion & $\begin{array}{l}\text { Justification of the criterion } \\
\end{array}$ & Indicator units \\
\hline 1. & $\begin{array}{l}\text { Soil } \\
\text { productivity } \\
\text { score }\end{array}$ & $\begin{array}{l}\text { An indicator of the ability of soil to provide plants with } \\
\text { nutrients. The higher the soil productivity score, the } \\
\text { more suitable the soil for intensive agriculture. }\end{array}$ & $\begin{array}{l}\text { Specific criterion indicator indicating soil } \\
\text { productivity scores. }\end{array}$ \\
\hline 2. & Population & $\begin{array}{l}\text { The settlement of territories shows the possibilities of } \\
\text { territorial development and the level of urbanization of } \\
\text { the area. }\end{array}$ & $\begin{array}{l}\text { Specific indicator of the criterion, } \\
\text { expressed in terms of population per unit. }\end{array}$ \\
\hline 3. & $\begin{array}{l}\text { Prevalence of } \\
\text { crop areas }\end{array}$ & $\begin{array}{l}\text { An indicator showing the intensity of economic activity } \\
\text { development in the area. }\end{array}$ & $\begin{array}{l}2 \text { - high prevalence; } 1 \text { - average prevalence; } \\
0 \text { - low prevalence. }\end{array}$ \\
\hline 4. & $\begin{array}{l}\text { Prevalence of } \\
\text { drained land }\end{array}$ & An indicator showing the suitability of land for farming. & $\begin{array}{l}2 \text { - high prevalence; } 1 \text { - average prevalence; } \\
0 \text { - low prevalence. }\end{array}$ \\
\hline 5. & $\begin{array}{l}\text { Prevalence of } \\
\text { protected areas }\end{array}$ & $\begin{array}{l}\text { An indicator showing the prevalence of territories where } \\
\text { the aim is to conserve the territory's natural resources. } \\
\text { Economic activity is restricted in these territories. }\end{array}$ & $\begin{array}{l}1 \text { - the territory falls into protected areas; } 0 \\
- \text { the territory is not included in the } \\
\text { protected areas. }\end{array}$ \\
\hline 6. & $\begin{array}{l}\text { Prevalence of } \\
\text { abandoned land }\end{array}$ & $\begin{array}{l}\text { An indicator showing the prevalence of territories } \\
\text { overgrown with woody plants. These territories are not } \\
\text { used for intensive agricultural activities due to certain } \\
\text { soil characteristics. }\end{array}$ & $\begin{array}{l}2 \text { - high prevalence; } 1 \text { - average prevalence; } \\
0 \text { - low prevalence. }\end{array}$ \\
\hline 7. & $\begin{array}{l}\text { Distribution of } \\
\text { lakes }\end{array}$ & $\begin{array}{l}\text { An indicator showing the possibilities of recreation in } \\
\text { the territory by using the available natural resources. }\end{array}$ & $\begin{array}{l}1 \text { - high prevalence of lakes; } 0-\text { low } \\
\text { prevalence of lakes. }\end{array}$ \\
\hline 8. & $\begin{array}{l}\text { Number of } \\
\text { organic farms }\end{array}$ & $\begin{array}{l}\text { An indicator showing the potential for the development } \\
\text { of organic and sustainable farming. The number of } \\
\text { existing organic farms indicates the perspective of the } \\
\text { activities carried out. }\end{array}$ & $\begin{array}{l}\text { Specific criterion indicator indicating the } \\
\text { number of organic farms, in units. }\end{array}$ \\
\hline 9. & $\begin{array}{lr}\begin{array}{l}\text { Prevalence } \\
\text { of } \\
\text { wetlands and } \\
\text { peatlands }\end{array} & \end{array}$ & $\begin{array}{l}\text { Indicator showing the possibility of exploiting areas for } \\
\text { extensive agriculture using available resources. E.g., it } \\
\text { is advisable to grow blueberries in peatlands and } \\
\text { cranberries in wetlands without using additional } \\
\text { chemical fertilizers. }\end{array}$ & $\begin{array}{l}2 \text { - high prevalence; } 1 \text { - average prevalence; } \\
0 \text { - low prevalence. }\end{array}$ \\
\hline 10. & Forest cover & $\begin{array}{l}\text { Indicator showing the suitability of territories for the } \\
\text { development and recreation of forest areas }\end{array}$ & 1 - high forest cover; 0 - low forest cover. \\
\hline 11. & Landscape & $\begin{array}{l}\text { An indicator that determines the attractiveness of an } \\
\text { area. The more picturesque the area, the more people it } \\
\text { attracts. }\end{array}$ & $\begin{array}{l}2 \text { - attractive landscape; } 1 \text { - moderately } \\
\text { attractive landscape; } 0 \text { - unattractive } \\
\text { landscape. }\end{array}$ \\
\hline 12. & $\begin{array}{l}\text { Number of } \\
\text { places to visit }\end{array}$ & $\begin{array}{l}\text { An indicator showing the development opportunities of } \\
\text { territories from a recreational point of view. The more } \\
\text { places to visit, the greater the potential for recreational } \\
\text { development. }\end{array}$ & $\begin{array}{l}\text { Specific indicator of the criterion, } \\
\text { expressed in the number of places to visit, } \\
\text { in units. }\end{array}$ \\
\hline 13. & $\begin{array}{l}\text { Number of } \\
\text { recreational and } \\
\text { rural tourism } \\
\text { homesteads }\end{array}$ & $\begin{array}{l}\text { Indicator showing the possibilities of rural tourism } \\
\text { development. The number of existing rural tourism } \\
\text { homesteads shows the perspective of the activities. }\end{array}$ & $\begin{array}{l}\text { Specific indicator of the criterion } \\
\text { indicating the number of rural tourism } \\
\text { homesteads, in units. }\end{array}$ \\
\hline
\end{tabular}

The data of the respective criteria were collected using data sets published on the Lithuanian Spatial Information Portal (www.geoportal.lt) and the Lithuanian Land Information System Portal (www.zis.lt):

1. M 1: 10000 digital raster orthophotographic map ORT10LT of the territory of the Republic of Lithuania, covering the entire territory of Lithuania.

2. Spatial data set Mel_DB10LT of land reclamation condition and waterlogging of the territory of the Republic of Lithuania M 1: 10000.

3. Soil data set Dirv_DR10LT of the territory of the Republic of Lithuania M 1: 10000.

4. Data set of the territory of the Republic of Lithuania M 1: 10000 abandoned lands AŽ_DRLT.

Also, the statistical data of the Land Fund of the Republic of Lithuania obtained from the National Land Service under the Ministry of Agriculture, the Agricultural and Rural Business Center and the official website of Moletai District Municipality (www.moletai.lt) were used during the research.

Based on the results of the study, the relevant conclusions were formulated based on the method of generalization.

\section{RESULTS}

Currently, the use, protection and development of the Moletai district territory is regulated by the correction of the Molètai district GP, approved by the Molètai district municipal council decision of October 25, 2018 No. B1-238 "On approval of the correction of the GP of the territory of Molètai district municipality". Correction of the GP of Moletai district was carried out to correct the technical errors, closing gaps in solutions, resolving conflicts of existing solutions, etc. 
According to the drawing of the functional priorities of the use of the territory of Moletai district GP, it can be seen that until 2018 the zone was dominated by the zone of intensive agricultural and forestry activities and the functional zone of forestry purposes. In the zone of intensive agricultural and forestry activities, the development of mixed specialization farms and the cultivation of commercial agricultural products were envisaged. The functional zone of forestry provides for the use of territories by increasing forest areas, restoring felled forests, and maintaining the species diversity of forests. The drawing of the functional zones of the use of the Moletai district territory also shows that in the north-eastern and southern parts of the district an extensive farming zone was envisaged, characterized by sustainable and ecological farming, and low-value land was recommended to be afforested. Areas of influence of promising residential areas were planned around the town of Molètai, on both sides of the country road Ukmergè - Molètai, in the direction of Ukmerge and around the towns and larger villages in the district. Urban development of other land in Molètai district was planned on both sides of the Vilnius - Utena main road. Recreational areas are provided mainly around water bodies.

After the approval of the correction of the GP of Moletai district, it can be seen that in the territory of the district an intensive zone of specialized farms and agriculture and a zone of forests and wooded territories remain and dominate. In the intensive zone of specialized farms and agriculture, the development of mixed specialization farms and the cultivation of branded agricultural products is recommended, taking into account the soil. In the area of forests and wooded areas, forests are divided into four groups according to their farming objectives, regime and main purpose: reserve forests, special purpose forests, protection forests and commercial forests. When new afforestation is envisaged, forests are assigned to the group to which the adjacent forests belong. The area of extensive specialized farms and agricultural areas is located next to the areas of forests and wooded areas. This location of this zone was determined by the low soil productivity score, the predominant soil granulometric composition, and land abandonment. It is recommended to consider sustainable and organic farming as the main activity in this area. The map of the Land Use and Protection Regulations of the correction of the district GP also identifies the territories where the development of residential areas is possible. The residential area is located around the town of Moletai, the territories of towns and larger villages in the district, and on both sides of the Ukmergè-Moletai country road, in the direction of Ukmergè. The residential area envisages the use of territories for the construction of one-apartment and two-apartment buildings, the construction of multi-apartment and dormitory buildings, social infrastructure, industry and storage, engineering infrastructure, water supply wells and common areas.

As Moletai district is also called the "land of lakes" and is characterized by the abundance of water bodies, there is a water zone in the whole territory of the district, next to which there is a recreational agricultural territory with the most valuable natural and aesthetic resources. Zone of mixed territories, planned in the zone of the section of the Vilnius - Utena highway located in the territory of Molètai district.

After a more detailed comparison of the use of the territories of 11 district elderships, the change envisaged in the solutions of the GP and the correction of the GP solutions did not reveal any significant changes in the regulation of the use of the territory. Minimum changes are identified in the solutions of the following eldership territory planning documents:

Giedraičiai eldership. In the GP of Molètai district, urban development was planned in the territory along the Vilnius - Utena highway. GP correction includes a mixed zone on both sides of the Vilnius - Utena highway. In the mixed zone, the types of use of the territory shall be determined in accordance with the possible land use purposes and methods established in the special plan of the territory of Moletai district located in the area of the Vilnius - Utena section of the highway. According to the GP, in the part of the territory of Giedraičiai eldership located between the Vilnius - Utena highway and the old Molètai highway, urban development, extensive and intensive areas of agricultural and forestry activities and areas of influence of promising residential areas were envisaged. According to the GP correction, the mentioned part of the territory is classified as a mixed zone (Figure 2).

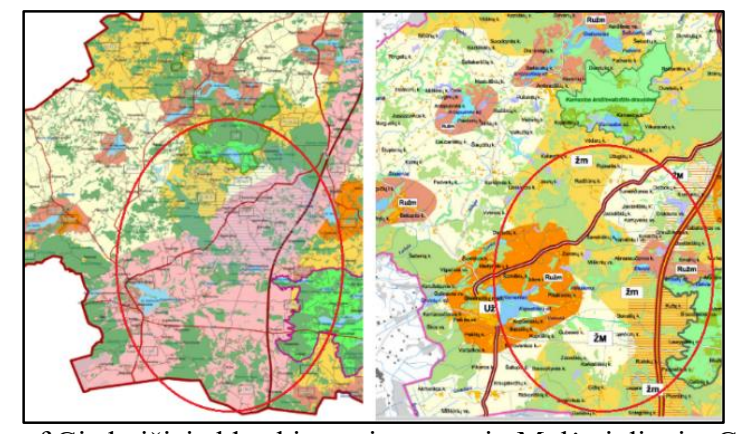

Figure 2. Regulation of Giedraičiai eldership territory use in Molètai district GP correction and GP

It can be seen from the fragments of the drawings that in the territory of the impact areas of perspective settlements planned in the territory of GP Giedraičiai eldership, according to the currently valid correction of the GP, a mixed zone is planned. In the eastern part of the territory of Giedraičiai eldership there is an intensive zone of specialized farms and agricultural territories. Meanwhile, an extensive zone of specialized farms and agricultural territories is planned in the northern and eastern parts of the eldership, next to the zone of forests and wooded territories.

Joniškis eldership. According to the GP and GP correction of the Moletai district territory, an intensive zone of specialized farms and agricultural territories is envisaged in the major part of Joniškis territory. However, in the eastern 
part of the eldership, according to the GP, forestry land areas were planned, and according to the GP correction, an extensive zone of specialized farms and agricultural territory was planned in this territory next to forests and wooded areas (Figure 3).

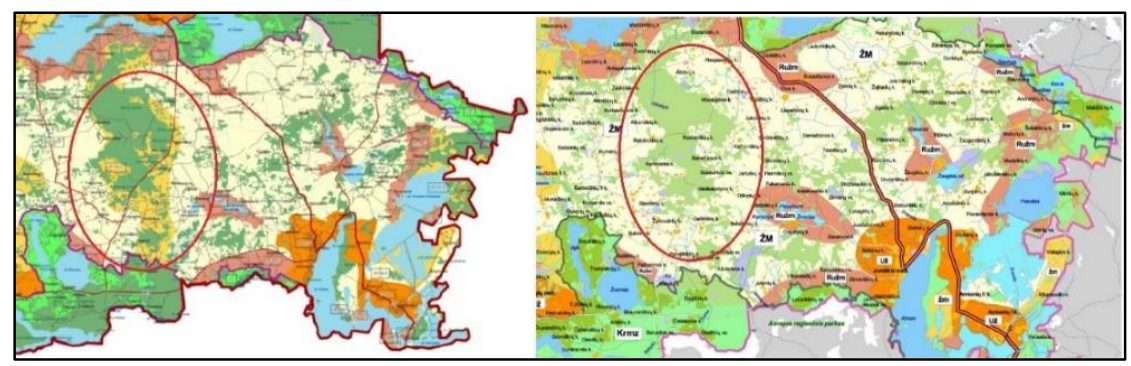

Figure 3. Regulation of Joniškis eldership territory use in Moletai district GP correction and GP

Luokesa eldership. The Vilnius - Utena highway runs through the Luokesa eldership in a north-south direction. Similarly to the territory of Giedraičiai eldership, urban development was planned in GP on both sides of the highway. The current correction of the GP on both sides of the Vilnius - Utena highway provides for a mixed zone. A residential area is planned in the northern part of Luokesa eldership. In the eastern part of the territory of the eldership there is an extensive zone of specialized farms and agricultural territories, and in the western part - an intensive zone of specialized farms and agricultural territories.

Suginčiai eldership. On both sides, on the north-west direction of the highway Vilnius - Utena, through the territory of Suginčiai eldership, the correction of GP provides for a mixed functional zone of territorial use. Meanwhile, in the above-mentioned part of the eldership territory, urban development was planned in the Moletai district GP. In the north-eastern part of the eldership there is an extensive zone of specialized farms and agricultural territories, and in the western part - an intensive zone of specialized farms and agricultural territories. In the east of the eldership, there is a zone of forests and wooded territories and a zone of state parks and reserves. Territories of recreational use are planned around water bodies not bordering on forested territories.

Thus, a comparison of the use of the territories of 11 Moletai district elderships provided for in the GP and GP correction showed that according to the Moletai district GP correction, a mixed zone was planned in the area of Vilnius Utena section, while Moletai GP planned urban development in this territory. It should be noted that the activities in the mixed zone are envisaged in accordance with the established purpose of the land plot and the method of use provided for in the special plan. According to the special plan, various zones of territorial use are envisaged in the planned territory located in the section of the Vilnius - Utena highway: agricultural land territories, residential territories, territories of industrial and storage or commercial objects, recreational territories. It should be noted that no substantial changes are planned in the drawing of functional zones for the use of GP correction territories, and the explanation note for GP correction states: fully adapted to the currently valid Territory Planning norms (approved by Order No. D1-7 of the Minister of Environment of the Republic of Lithuania of 2 January 2014). For this, it would be necessary to prepare a fundamentally new GP of the territory of Molètai district municipality. "(Molètai district ..., 2018). Considering that in Moletai district it was not possible to substantially change the functional zoning of the territories, as the GP correction was prepared and not the GP change, and the functional zoning currently planned in the district does not fully comply with the territory planning norms, it can be concluded that the circumstances regarding the need to change or correct the GP have not been sufficiently assessed in the present case.

In order to determine whether the territories of Molètai district are used in accordance with the functional zoning of the territories established in the GP correction, using the latest orthophotographic material, the analysis of the compliance of the current situation of the eldership territories with the GP correction solutions was performed. Five problem territories have been singled out from different elderships, where the visible use of the territories does not comply with the regulation of the use of territories provided for in the GP correction.

The first problem territory was identified in Dubingiai eldership, where the actual use of the territories does not comply with the regulations on the use of territories determined in the GP correction (Figure 4).

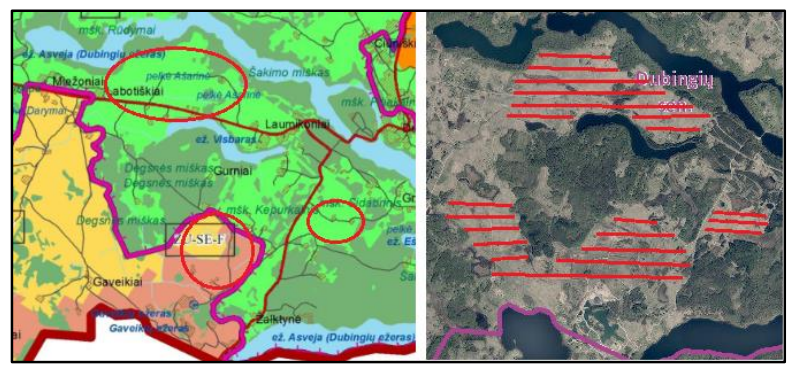

Figure 4. Actual use of part of Dubingiai eldership territory

The right side of the figure shows an excerpt from the GP correction, which shows that the red-marked parts of the territory include zones of forests and wooded areas, state parks and nature reserves. Meanwhile, from the orthophoto 
material on the left, it was found that the areas marked in red are dominated by meadows and pastures and cultivated fields. In this context, it can be assumed that the actual use of the site does not comply with the land use regulation set out in the GP correction.

The second problem territory was identified in Joniškis eldership, where taking into account the actual use of the territory, it might be expedient to change the regulation of the use of the territory in the GP (Figure 5).

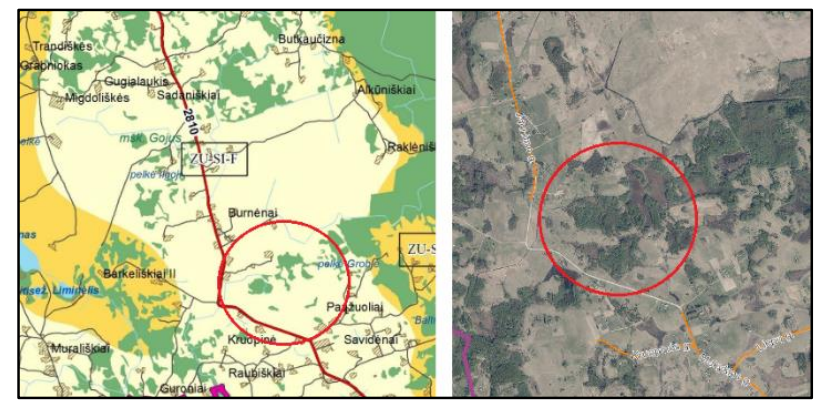

Figure 5. Actual use of part of Joniškis eldership territory

The right side of the figure shows an excerpt from the GP correction, which shows that an intensive zone of specialized farms and an agricultural territory with areas of forests and wooded areas is identified in the red-marked part of the territory. The actual use of the territory shows that the wooded areas are spread over a larger area than expected. In this context, it can be assumed that the suitability of the designated area for economic activity should possibly be assessed and provided for in the GP.

The third problem territory was identified in Giedraičiai eldership, where taking into account the actual use of the territory, it might be expedient to change the regulation of the use of the territory in the GP (Figure 6).

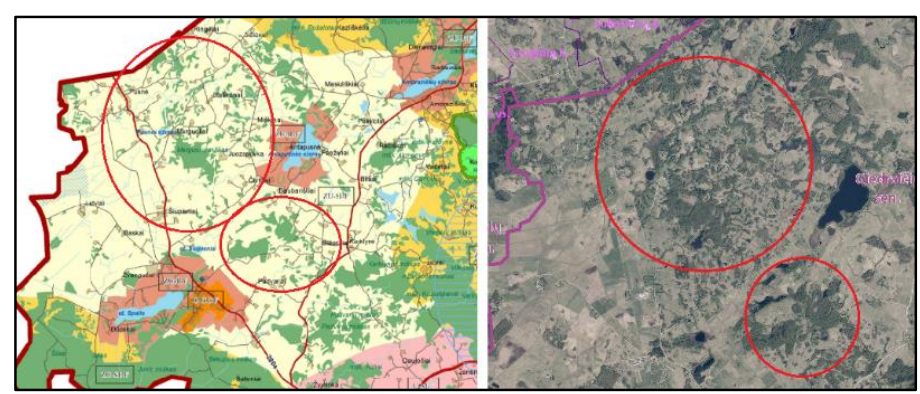

Figure 6. Actual use of a part of the territory of Giedraičiai eldership

The right side of the figure shows an excerpt from the GP correction, which shows that an intensive zone of specialized farms and an agricultural territory with areas of forests and wooded areas is identified in the red-marked part of the territory. According to the actual use of the territory, analogously to the analyzed part of Joniškis eldership, it can be seen that the forest areas are spread over a larger area than planned. In this context, it can be assumed that the suitability of the designated area for economic activity should possibly be assessed and provided for in the GP.

The fourth problem territory has been identified in Videniškès eldership, where, taking into account the actual use of the territory, it might be expedient to change the regulation of the use of the territory in the GP (Figure 7).

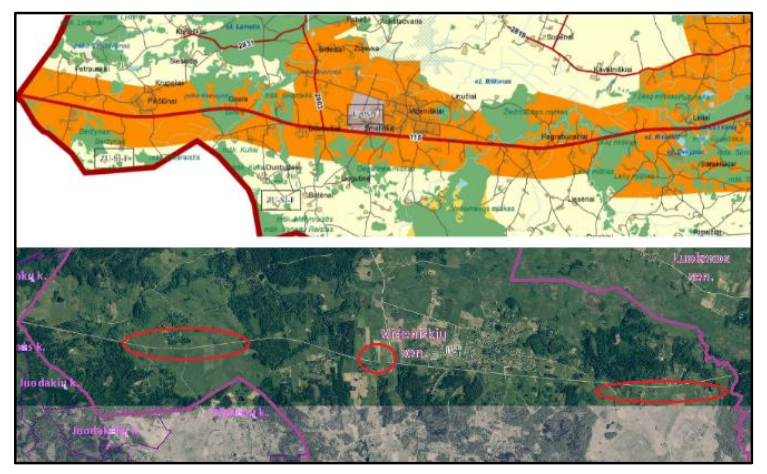

Figure 7. Actual use of a part of the territory of Videniškès eldership

On the right side of the figure there is a fragment from the GP correction, which shows that in the territory located in the zone of the district road Ukmerge - Moletai section, there is a residential area, an industrial and storage area and a forest and wooded area. According to the actual use of the territory, in the analyzed part of the territory the residential area is only near Videniškiai village. The information in the figure shows that the part of the territory in question is dominated by arable land, meadows and pastures as well as forest areas. In view of this, it can be assumed that it is 
possible to assess the possibilities of development of residential areas in the part of the territory in question or to assess the expediency to change the regulation of land use provided for in the GP.

The fifth problem territory was identified in Alanta eldership, where, taking into account the actual use of the territory, it might be appropriate to change the regulation of the use of the territory in the GP (Figure 8).

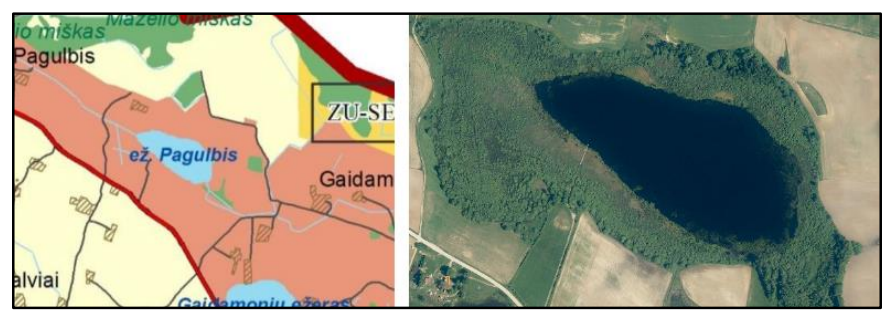

Figure 8. Actual use of a part of the territory of Alanta eldership

On the right side of the figure, there is a fragment from the GP correction, which shows that in the territory around Lake Pagulbis in the GP correction, the zone of recreational agricultural territory has been established. According to the actual use of the territory, the swamp and forest areas predominate around Lake Pagulbis. In this context, it can be assumed that the suitability of the designated territory for recreational activities should possibly be assessed, and this should be provided for in the GP or measures for adapting the territory to recreational use.

After performing a multicriteria perspective analysis of the development of the territories of Moletai district elderships, it was established that the most promising elderships for intensive agricultural activities are Joniškis, Balninkai and Alanta (priority criteria for soil productivity, crops, land drainage and abandoned land distribution). Meanwhile, the elderships, where according to the set criteria it is not recommended to develop intensive agricultural activities, are Čiulènai and Mindūnai (territories are characterized by high forest cover and fall into protected areas) (Figure 9).

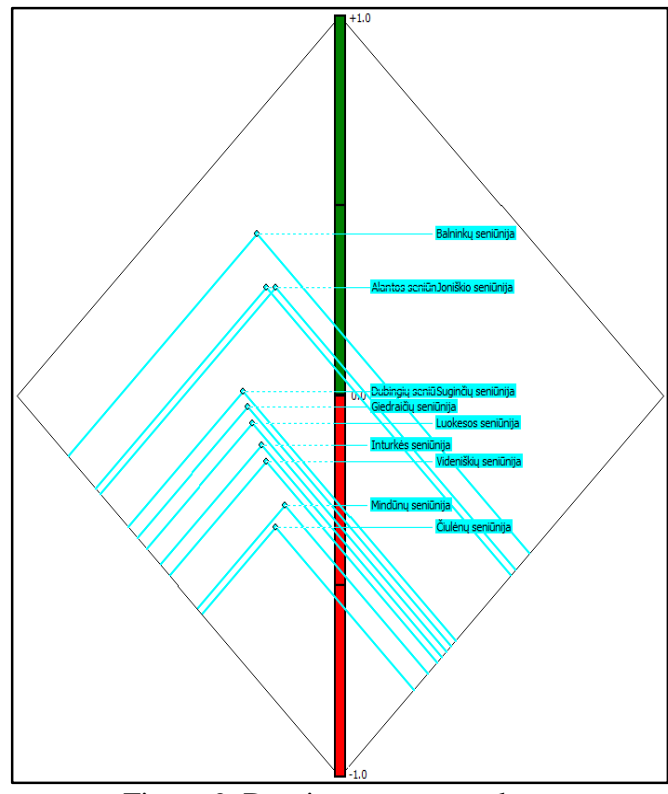

Figure 9. Dominance test results

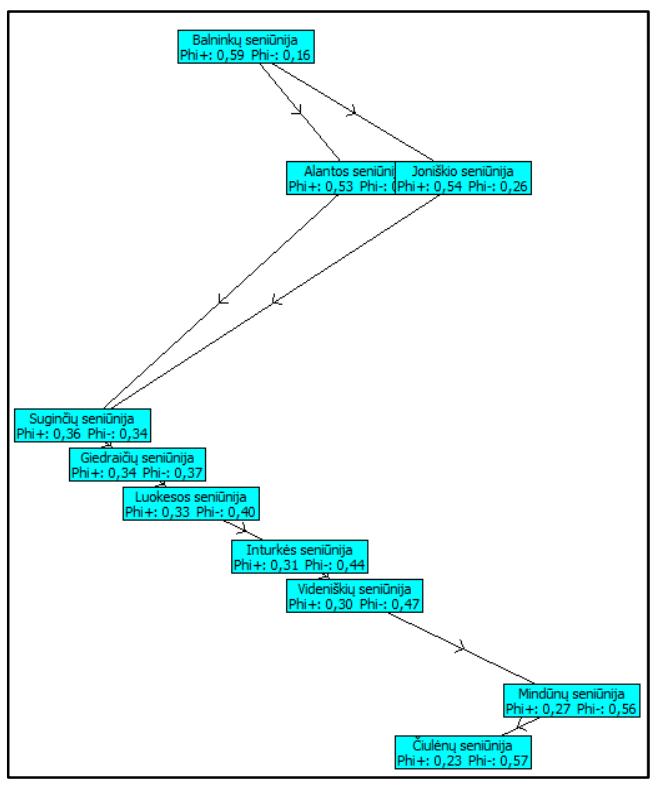

Figure 10. Network test results

The Network test revealed that Balninkai eldership with the highest value of priority $(\max )$ criteria $(\mathrm{Phi}+=0.59)$ and the lowest value of non-priority $(\mathrm{min})$ criteria $(\mathrm{Ph}-=0.16)$ is the most suitable for the development of intensive agriculture in Moletai district (Figure 10). This eldership is characterized by exceptionally low forest cover (compared to other elderships), high prevalence of crop areas and drained lands, therefore it is most expedient to develop intensive agriculture in it.

In determining the most promising eldership for the development of extensive agriculture, the following criteria were prioritized: the number of organic farms, the prevalence of wetlands and peatlands, the prevalence of abandoned lands and cropland areas. It was established that the most promising elderships for the development of extensive farming are in Giedraičiai, Balninkai and Alanta. Meanwhile, the elderships where the development of extensive agriculture is not recommended according to the set criteria are Mindūnai, Čiulènai and Inturkè (Figure 11). 


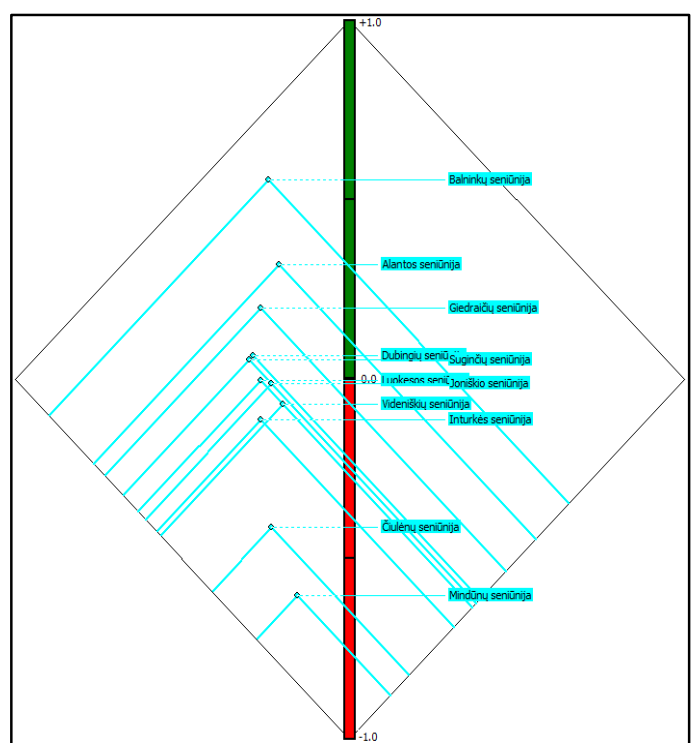

Figure 11. Dominance test results

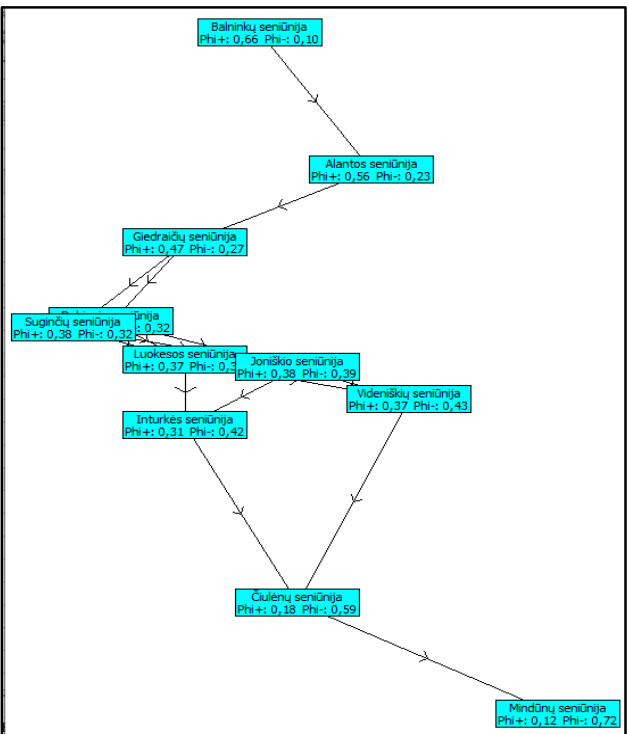

Figure 12. Network test results

The same as for the development of intensive agriculture, the most suitable for the development of extensive agriculture is Balninkai eldership, the highest value of priority criteria (Phi $+=0.66$ ) and the lowest value of non-priority criteria (Phi- $=0.10$ ) (Figure 12). The eldership has the largest number of organic farms and a high distribution of abandoned lands, wetlands and peatlands.

It is expedient to develop forest territories in Mindūnai, Dubingiai, Čiulènai and Videniškès elderships (the following criteria have been prioritized: forest cover, distribution of protected territories, distribution of abandoned land and distribution of lakes) (Figure 13).

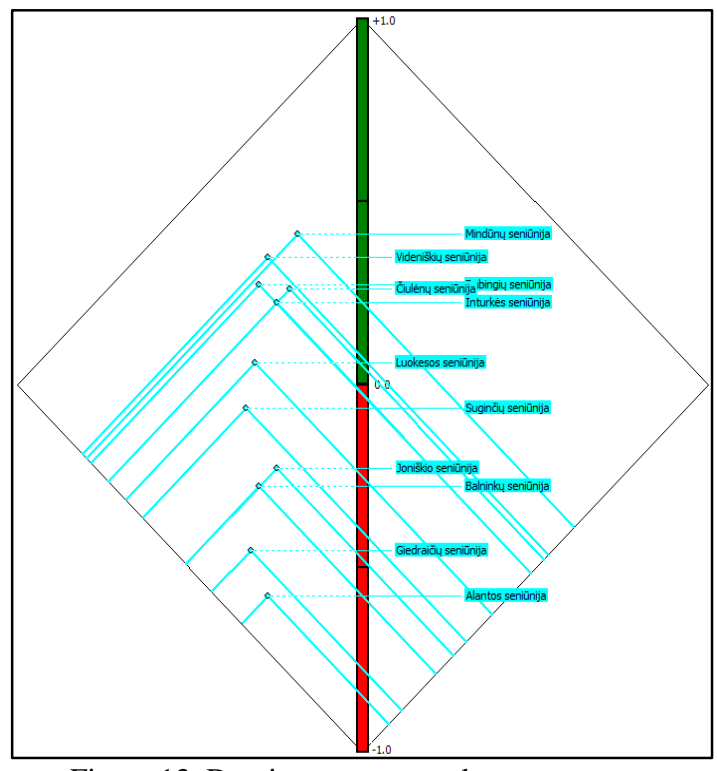

Figure 13. Dominance test results

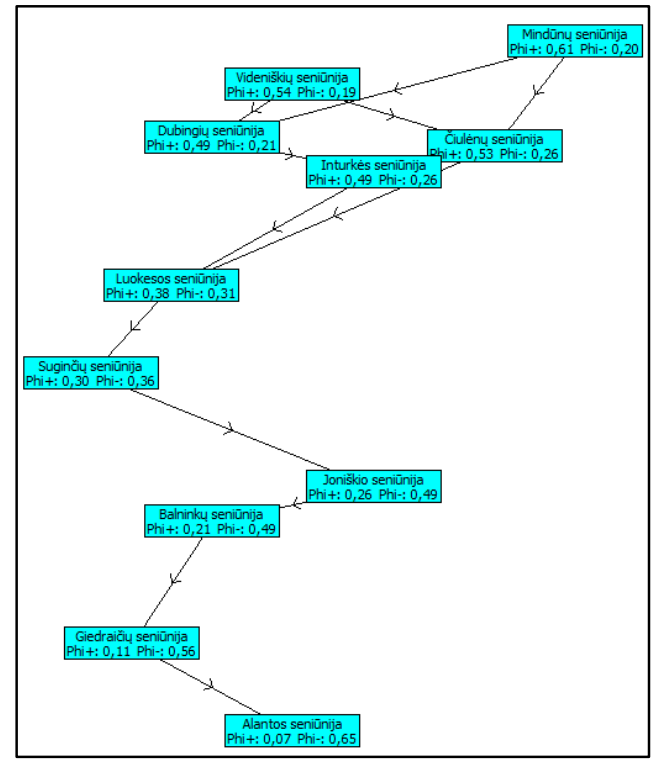

Figure 14. Network test results

The most promising eldership for the development of forest areas is Mindūnai eldership $(\mathrm{Ph}+=0.49 ; \mathrm{Phi}-=0.21)$ (Figure 14). This eldership is characterized by high forest cover, low soil productivity score, abundance of abandoned land and access to protected territories. Meanwhile, the eldership in which the development of forested areas is most not recommended, according to the set criteria, is Alanta. Such results are influenced by low forest cover, high prevalence of agricultural land and fertile soil.

The most suitable elderships for the development of perspective recreation were determined by prioritizing the criteria of landscape, forest cover, distribution of protected territories, number of places of interest and number of rural tourism homesteads. The most promising areas for recreation development in Mindūnai, Dubingiai and Čiulènai have been identified. Meanwhile, Joniškis, Alanta and Inturkè are the elderships where the development of forest areas is not recommended according to the set criteria (Figure 15). 


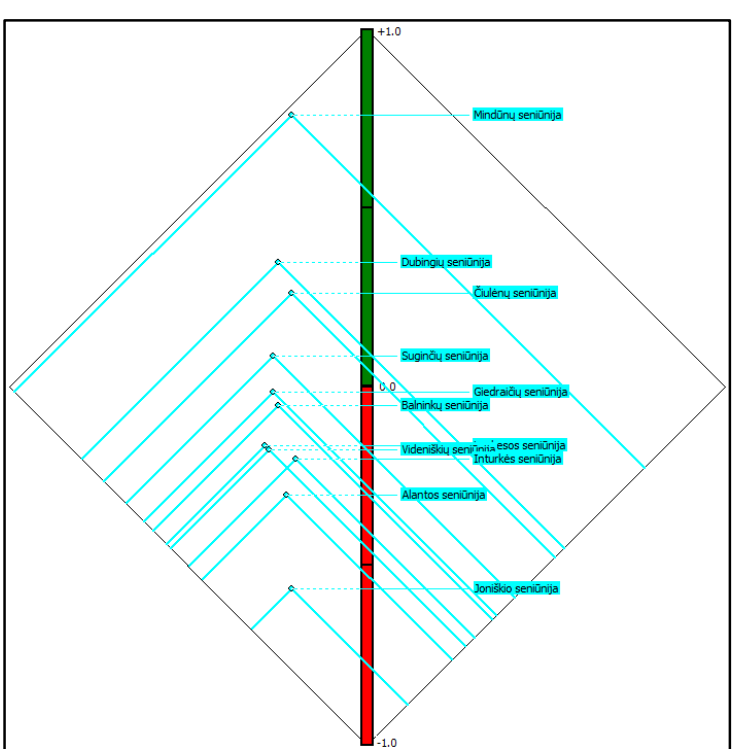

Figure 15. Dominance test results

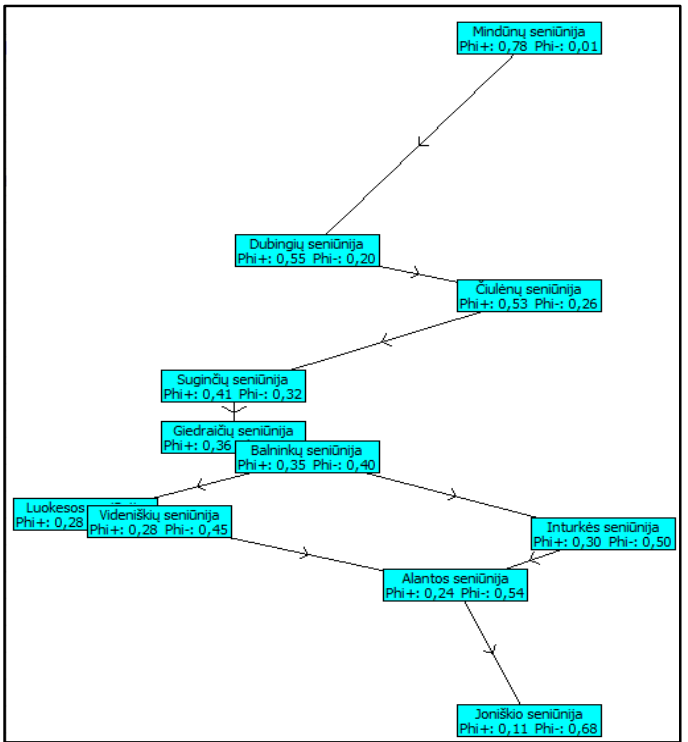

Figure 16. Network test results

The most attractive eldership for the development of recreation as well as for the development of forest territories is Mindūnai eldership $(\mathrm{Ph}+=0.78$; Phi- $=0.01)$, characterized not only by the above-mentioned large forest cover, but also by attractive landscape, abundance of places of interest and large lakes (Figure 16). Meanwhile, the most unsuitable eldership for the development of recreation is Joniškis eldership, which is characterized by rather large areas of abandoned lands, a small number of objects to visit and lake nature.

According to the results of the multicriteria analysis, it was also found that there is no single dominant perspective direction of territory development in Suginčiai, Luokesa and Inturkè elderships according to the set criteria. The results of the analysis show that the highest values of the priority alternatives in both elderships, in all four directions of territory development, prevail about zero. Such results may have been influenced by the diversity of natural resources in the elderships.

Summarizing the results obtained during the research, a comparative analysis of GP correction solutions, actual use of territories and identified perspective areas of development directions was performed, the summary results of which are summarized and presented in Table 2.

Table 2. Summary of GP solutions, territories use and development perspectives of Molètai district elderships

\begin{tabular}{|c|c|c|c|}
\hline Eldership & GP correction solutions & Actual use of territories & $\begin{array}{l}\text { Territory development } \\
\text { perspectives }\end{array}$ \\
\hline Alanta & $\begin{array}{l}\text { Intensive zone of specialized farms and } \\
\text { agriculture; zone of forests and wooded } \\
\text { territories. }\end{array}$ & $\begin{array}{l}\text { Intensive and extensive agriculture, } \\
\text { dense distribution of homesteads in the } \\
\text { whole territory of the eldership. }\end{array}$ & $\begin{array}{l}\text { Intensive and extensive } \\
\text { agriculture }\end{array}$ \\
\hline Balninkai & $\begin{array}{l}\text { Intensive zone of specialized farms and } \\
\text { agriculture; agricultural territories for } \\
\text { recreational use. }\end{array}$ & $\begin{array}{l}\text { Intensive and extensive agriculture, } \\
\text { forests and wooded territories. }\end{array}$ & $\begin{array}{l}\text { Intensive and extensive } \\
\text { agriculture }\end{array}$ \\
\hline Čiulènai & Zone of forests and wooded territories. & $\begin{array}{l}\text { Intensive and extensive agriculture, } \\
\text { forests and wooded territories. }\end{array}$ & $\begin{array}{l}\text { Forests and wooded territories, } \\
\text { recreation. }\end{array}$ \\
\hline Dubingiai & $\begin{array}{l}\text { Extensive specialized farms and agricultural } \\
\text { zone; zone of forests and wooded territories. }\end{array}$ & $\begin{array}{l}\text { Intensive and extensive agriculture, } \\
\text { forests and wooded territories. }\end{array}$ & $\begin{array}{l}\text { Recreation, forests and wooded } \\
\text { territories. }\end{array}$ \\
\hline Giedraičiai & $\begin{array}{l}\text { Intensive zone of specialized farms and } \\
\text { agriculture; extensive zone of specialized } \\
\text { farms and agriculture; mixed zone. }\end{array}$ & $\begin{array}{l}\text { Intensive and extensive agriculture, } \\
\text { forests and wooded territories. }\end{array}$ & Extensive agriculture \\
\hline Joniškis & $\begin{array}{l}\text { Intensive zone of specialized farms and } \\
\text { agriculture. }\end{array}$ & $\begin{array}{l}\text { Intensive and extensive agriculture, } \\
\text { forests and wooded territories. }\end{array}$ & Intensive agricultute \\
\hline Inturkè & $\begin{array}{l}\text { Intensive zone of specialized farms and } \\
\text { agriculture; extensive zone of specialized } \\
\text { farms and agriculture; zone of forests and } \\
\text { wooded territories. }\end{array}$ & $\begin{array}{l}\text { Forests and wooded territories, } \\
\text { intensive agriculture. }\end{array}$ & $\begin{array}{l}\text { Intensive and extensive } \\
\text { agriculture, forests and wooded } \\
\text { territories, recreation. }\end{array}$ \\
\hline Luokesa & $\begin{array}{l}\text { Residential area; mixed zone, zone of forests } \\
\text { and wooded territories. }\end{array}$ & $\begin{array}{l}\text { Forests and wooded territories, } \\
\text { residential areas, intensive agriculture. }\end{array}$ & $\begin{array}{l}\text { Intensive and extensive } \\
\text { agriculture, forests and wooded } \\
\text { territories, recreation. }\end{array}$ \\
\hline Mindūnai & $\begin{array}{l}\text { Zone of forests and wooded territories, } \\
\text { functional zone of state parks and reserves. }\end{array}$ & $\begin{array}{l}\text { Forests and wooded territories, } \\
\text { recreation. }\end{array}$ & $\begin{array}{l}\text { Forests and wooded territories, } \\
\text { recreation. }\end{array}$ \\
\hline Suginčiai & $\begin{array}{l}\text { Intensive zone of specialized farms and } \\
\text { agriculture. }\end{array}$ & Intensive agriculture. & $\begin{array}{l}\text { Intensive and extensive } \\
\text { agriculture, forests and wooded } \\
\text { territories, recreation. }\end{array}$ \\
\hline Videniškiai & $\begin{array}{l}\text { Residential area; intensive zone of } \\
\text { specialized farms and agriculture; zone of } \\
\text { forests and wooded territories. }\end{array}$ & $\begin{array}{l}\text { Forests and wooded territories, } \\
\text { intensive agriculture. }\end{array}$ & Forests and wooded territories. \\
\hline
\end{tabular}


As can be seen in the table above, according to the GP correction solutions, 2 - 3 dominant directions of land use and development in each eldership have been singled out. After determining the development perspectives of Molètai district territories and comparing the obtained results with GP correction solutions and actual use of territories in the area, it was established that at least one of the functional zones of territories regulated in GP correction coincides with actual use and territory development perspective. The biggest discrepancy between the regulated, existing and perspective use of the territories was found in Videniškiai, Dubingiai and Giedraičiai elderships. Meanwhile, in Mindūnai, Joniškis and Balninkai elderships, the actual use of territories is regulated in the GP correction, and it mostly corresponds to the planned perspectives of territory development.

\section{CONCLUSIONS}

1. After the comparative analysis of the functional zoning solutions of the GP and GP correction of the territories of 11 Molètai district elderships, it was established that no significant changes have been identified in the regulation of the use of the territory. Since the GP correction was prepared, not the GP change and the functional zoning of the land use currently envisaged in the district is not fully in line with the territory planning norms, it can be concluded that the circumstances regarding the need to change or correct the GP in general have not been sufficiently assessed. Meanwhile, after analyzing the compliance of the actual land use of the Moletai district territory with the solutions of the GP correction, land use and protection regulations drawing, it was established that recreational areas around Lake Pagulbis in Alanta eldership are planned, but according to the current situation in the territories of Giedraičiai and Joniškis elderships (according to the solutions provided in the GP correction), the territories are intended for intensive agricultural activities, but forested areas predominate here.

2. The analysis of the development perspectives of the territories of Moletai district elderships revealed that it is expedient to develop intensive agriculture in Joniškis, Balninkai and Alanta elderships. Extensive agriculture - in Balninkai, Alanta and Giedraičiai elderships. According to the set criteria, the territories are the most suitable for the development of forests in Mindūnai, Čiulènai and Videniškiai elderships. These elderships are characterized by high forest cover, low soil productivity score, abundance of abandoned lands and access to protected territories. Meanwhile, it is most expedient to develop recreation in Mindūnai, Čiulènai and Dubingiai elderships, which are characterized by an abundance of natural and cultural resources that attract tourists.

3. After determining the development perspectives of Moletai district territories and comparing the obtained results with GP correction solutions and actual use of territories in the area, it was established that at least one of the functional areas of territories regulated in GP correction coincides with actual use and territory development perspective. The biggest discrepancy between the regulated, existing and perspective use of the territories was found in Videniškiai, Dubingiai and Giedraičiai elderships. Meanwhile, in Mindūnai, Joniškis and Balninkai elderships, the actual use of territories is regulated in the GP correction, and it mostly corresponds to the planned perspectives of territory development.

\section{REFERENCES}

1. Dringelis L. 2017. The reorganization of the institutional framework is an important precondition for improving the state of spatial planning and architecture in the country. Scientific-practical conference "Architectural quality assurance measures", p. 196 - 208 , Vilnius Gediminas Technical University (in Lithuanian).

2. European conference of ministers responsible for regional planning 1983. Torremolinas (Spain). Territory and landscape No.3. Interactive: https://www.ipcc.ch/pdf/assessment-report/ar5/wg3/ipcc_wg3_ar5_chapter11.pdf.

3. Yansui L., Yang Z. 2021.Territory spatial planning and national governance system in China. Land Use Policy, No. 102, p.1-9, Interactive:

https://reader.elsevier.com/reader/sd/pii/S0264837721000119?token=B405C9E4418733772CD76D1A08F33E86C4B36F85E37 B9CA331B50AF3F225678AB4E5C31D23B706D00C038336C0034E1E\&originRegion=eu-west1\&originCreation $=20210913121259$.

4. Koglin T, Pettersson F. 2017. Changes, Problems, and Challenges in Swedish Spatial Planning-An Analysis of Power Dynamics. Sustainability, 9(10). https://doi.org/10.3390/su9101836.

5. General plan of Lithuania 2030. Interactive: http://www.bendrasisplanas.lt/ (in Lithuanian).

6. Resolution of the Seimas of the Republic of Lithuania "On the General Plan of the Territory of the Republic of Lithuania"“. 2002 -10- 29 d., Nr. IX - 1154. New wording from 2006-10-12, i. k. 1021010NUTA0IX-115. Interactive: https://eseimas.lrs.lt/portal/legalAct/lt/TAD/TAIS.284909/asr (in Lithuanian).

7. Law on Territorial Planning of the Republic of Lithuania. 1995 -12- 12 d., Nr. I-1120. New wording from 2021-07-01, i. k. 0951010ISTA00I-1120 . Interactive: https://e-seimas.lrs.lt/portal/legalAct/lt/TAD/TAIS.23069 (in Lithuanian).

8. Treaty of Lisbon amending the Treaties establishing the European Union and the European Community. European Commission. Interactive: https://www.europarl.europa.eu/factsheets/lt/sheet/5/lisabonos-sutartis (in Lithuanian).

9. Local Strategic Partnership and Spatial Planning: a practical guide. 2007. London. Interactive: http://camdencen.org.uk/Resources/Planning/Communities/Planning\%20Together.pdf.

10. Municipality of Moletai district. Interactive: https://www.moletai.lt/go.php/2007-2013\%20m.\%20ivykdyti\%20projektai605 (in Lithuanian). 
11. Smith P., Clark H., Dong H., Elsiddig E., Haberl H., Harper R., House J., Jafari M. 2014. Chapter 11 - Agriculture, forestry and other land use (AFOLU). Climate Change 2014: Mitigation of Climate Change. IPCC Working Group III Contribution to AR5. Cambridge University Press, p. 811 - 922. Interactive:

12. Tiškus G. 2010. Bendrojo ir specialiojo teritorijų planavimo strategija ir praktika. Darnaus vystymosi strategija ir praktika, p. 17 29. Prieiga

per internetą:https://etalpykla.lituanistikadb.lt/object/LTLDB0001:J.04 2010 1367180588553/J.04 2010 1367180588553.pdf

13. Zabel F., Putzenlechner B., Mauser W. 2014. Global agricultural land resources - a high resolution suitability evaluation and its perspectives until 2100 under climate change conditions. Plosone, Vol. 9(9) e107522, p. 1-12. https://doi.org/10.1371/journal.pone.0107522 